Jurnal Bidan Cerdas
e-ISSN: 2654-9352 dan p-ISSN: 2715-9965
Volume 3 Nomor 3, 2021
DOI: $10.33860 /$ jbc.v3i3.467
Website: http://jurnal.poltekkespalu.ac.id/JBC
Penerbit: Poltekkes Kemenkes Palu

\title{
Pengaruh Terapi Akupresur terhadap Tingkat Kecemasan pada Ibu Hamil Trimester III
}

\author{
Ita Novianti $\square$, Asrianti Safitri Muchtar \\ Akademi Kebidanan Batari Toja Watampone \\ open
access \\ ĐEmail Korespondensi: ita.novianti91@gmail.com
}

\section{ARTICLEINFO}

\section{Article History:}

Received: 2021-07-31

Accepted: 2021-08-16

Published: 2021-08-31

\section{Kata Kunci: \\ Kecemasan; Kehamilan; Akupresur.}

\section{Keywords:}

Anxiety;

Pregnancy;

Acupressure.

\begin{abstract}
ABSTRAK
Pendahuluan: Prevalensi kecemasan kehamilan sekitar 14-54 \% paling tinggi pada trimester satu dan trimester tiga. Akupresur menarik perhatian sebagai terapi non-farmakologi untuk relaksasi alami. Tujuan penelitian ini untuk mengetahui pengaruh terapi akupresur terhadap tingkat kecemasan pada ibu hamil. Metode: Penelitian ini menggunakan rancangan quasi experiment dengan pendekatan pre and post test pada kelompok intervensi dan kelompok kontrol. Jumlah sampel 40 ibu hamil trimester III yang mengalami kecemasan. 21 sampel untuk kelompok intervensi dengan terapi akupresur dan 19 sampel untuk kelompok kontrol dengan terapi placebo. Pengukuran kecemasan menggunakan Hamilton Anxiety Rating Scale (HARS). Hasil: pada kelompok intervensi, rerata kecemasan sebelum intervensi adalah 26,6 dan setelah intervensi adalah 22,3 (nilai $p<0,001$ ), sedangkan pada kelompok kontrol adalah 26,1 sebelum dan 25,1 setelah intervensi (nilai $p=0,072$ ). Rerata penurunan tingkat kecemasan kehamilan kelompok intervensi lebih bermakna dibandingkan kelompok kontrol. Kesimpulan: Terapi akupresur berpengaruh secara signifikan terhadap penurunan tingkat kecemasan pada ibu hamil kelompok intervensi $(p<0,001)$ dan terapi akupresur dapat dijadikan sebagai salah satu metode non-farmakologis yang efektif untuk mengurangi gejala kecemasan pada kehamilan
\end{abstract} ABSTRACT
Introduction: The prevalence of pregnancy anxiety is around 14-54\%,
highest in the first and third trimesters. Acupressure attracts attention as a
non-pharmacological therapy for natural relaxation. The research aims to
determine the effect of acupressure therapy on anxiety levels. Method: This
study was conducted at the Health Centers of Tamalanrea Jaya and
Antang, the study used a quasi-experimental design with the pre and post
test approach in the intervention group and the control group. The total of
research subjects 40 trimester III pregnant mothers who had experience
anxiety. The intervention group (21 samples) with acupressure therapy and
the control group (19 samples) with placebo therapy. Measuring anxiety
using the Hamilton Anxiety Rating Scale (HARS). Result: in the intervention
group, the mean of anxiety before the intervention was 26.6 and after the
intervention was 22.3 (p value <0.001), while in the control group it was
26.1 before and 25.1 after the intervention (p value=0.072). The mean
reduction in pregnancy anxiety level in the intervention group was more
significant than the control group. Conclusion: Acupressure therapy has a
significant effect on decreasing anxiety levels in pregnant mothers in the
intervention group (p<0.001) and acupressure therapy can be used as one
of the effective non-pharmacological methods to reduce symptoms of
anxiety in pregnancy. C 2021 by the authors. Submitted for possible open access publication under the terms and
Commons Attribution (CC BY SA) license (https://creativecommons.org/licenses/by-sa/4.0/) 


\section{PENDAHULUAN}

Kecemasan adalah respon atau tanggapan psikologis terhadap suatu ancaman yang sumbernya tidak diketahui, internal, samar-samar, atau konfliktual, yang dapat berkembang menjadi suatu gangguan dan menetap pada individu (Videbeck, 2012). Kecemasan merupakan urutan kedua penyebab kecacatan di seluruh dunia (Abadi et al., 2018). Kecemasan pada kehamilan merupakan reaksi emosional yang terjadi terkait dengan kekhawatiran ibu terhadap janinnya, keberlangsungan kehamilan, persalinan, nifas dan masa ketika telah berperan menjadi ibu serta sebagai respon emosional terhadap ancaman yang dirasakan (Valiee, Bassampour and Nasrabadi., 2012), gejala yang menyedihkan, keprihatinan yang berkelanjutan, khawatir, perasaan tegang dan ketidakmampuan bersantai (Kuo et al., 2016; Kao et al., 2012).

Kecemasan pada ibu hamil merupakan masalah kesehatan yang paling umum sekitar $1 / 3$ dari wanita hamil mengalami gejala kecemasan selama hamil. Menurut Mizuno, Tamakhosi and Tanabe (2017) kecemasan kehamilan dapat terjadi 0,7 $2,8 \%$ pada wanita hamil. Sedangkan tingkat prevalensi depresi sekitar $12 \%$ dan tingkat prevalensi kecemasan sekitar 13\% (The British Psychological Society, 2018). Kecemasan akan dirasakan berbeda setiap trimester selama kehamilan dan prevalensi kecemasan kehamilan sangat bervariasi setiap trimester sekitar 14 - 54\%, paling tinggi pada trimester satu dan trimester tiga. Kecemasan juga sering dialami ibu primigravida (Lee et al., 2007; Madhavanprabhakaran et al., 2015; Siregar et al., 2021; Teixeira et al., 2009).

Dampak kecemasan pada ibu selama kehamilan beresiko tiga kali lipat mengalami postpartum blues dan depresi postpartum (Brummelte and Galea, 2010), peningkatan resiko tekanan darah tinggi dan penyakit jantung serta meningkatkan terjadinya keguguran (Vlenterie, Roeleveld and Gelder, 2016). Sedangkan pada perinatal berdampak terhadap peningkatan resiko hasil perinatal yang merugikan (Yuksel, Akin and Durna, 2010). Kecemasan kehamilan dikaitkan dengan kelahiran prematuritas, Bayi Berat Lahir Rendah (BBLR), skor APGAR rendah, mempengaruhi perkembangan saraf janin yang berkaitan dengan perkembangan kognitif, emosi dan perilaku sampai masa anak-anak (Qiao et al., 2012; Deklava et al., 2015).

Untuk mengantisipasi dampak tersebut terapi akupresur telah menarik perhatian sebagai terapi non farmakologis untuk mengurangi kecemasan. Akupresur merupakan pilihan terapi yang tidak berbahaya dan tidak memiliki efek samping karena bersifat non-invasif, hemat biaya dan dapat dilakukan oleh individu itu sendiri tetapi sebelumnya memerlukan pelatihan khusus. Beberapa titik akupresur dapat mengurangi kecemasan dengan memberikan rangsangan manual, sehingga dapat mengurangi kecemasan, mendorong terjadinya relaksasi dan langsung berpengaruh pada mekanisme patologis yang dapat mengarah pada depresi. Titik akupresur yang paling umum digunakan untuk mengurangi kecemasan yaitu yintang (EX-HN3) dan shenmen (HT-7) (Abadi et al., 2018; Arami et al., 2015; Kuo et al., 2016; Valiee et al., 2012)

Penelitian eksperimental mengenai efek akupresur pada kecemasan telah membuktikan bahwa akupresur dapat mengurangi kecemasan. Seperti Hasil Penelitian Kuo et al, penggunaan akupresur mengurangi kecemasan pada wanita post operasi Sectio Caesar. Tingkat kecemasan dan kelelahan pada kelompok ibu post operasi Sectio Caesar yang mendapatkan terapi shenmen auricular akupresur selama 5 hari mengalami penurunan dibandingkan dengan ibu yang mendapatkan perawatan biasa (Kuo et al., 2016). 
Berdasarkan studi pendahuluan yang dilakukan di Puskesmas Tamalanrea Jaya dan Puskesmas Antang Kota Makassar melalui wawancara langsung masing-masing puskesmas 5 ibu hamil trimester III yang diwawancara, 4 diantaranya di puskesmas Tamalanrea Jaya dan 3 diantaranya di puskesmas Antang mengalami kecemasan sejak masuk trimester III. Sedangkan puskesmas sendiri sampai saat itu belum memiliki prosedur atau program tetap dalam hal skrining masalah psikologi ibu hamil. Beberapa studi penelitian membuktikan bahwa akupresur dapat mengurangi kecemasan, akan tetapi belum terdapat penelitian yang menunjukkan pengaruh terapi akupresur untuk mengurangi kecemasan ibu hamil. Penelitian ini bertujuan untuk mengetahui pengaruh akupresur terhadap tingkat kecemasan pada ibu hamil.

\section{METODE PENELITIAN}

Rancangan penelitian yang digunakan pada penelitian ini adalah eksperimen semu (Quasi Eksperiment), dengan pendekatan pre and post test pada kelompok intervensi dan kelompok kontrol. Populasi dalam penelitian ini adalah seluruh ibu hamil trimester III yang berada di Puskesmas Tamalanrea Jaya dan Puskesmas Antang Kota Makassar. Penentuan jumlah sampel menggunakan rumus estimasi proporsi dan diperoleh 44 responden yang memenuhi kriteria inklusi yaitu bersedia menjadi responden, ibu dengan usia kehamilan 25-36 minggu, tingkat kecemasan ibu hamil pada kategori sedang, berat dan berat sekali dan usia 20-35 tahun (terjadi drop out 1 sampel pada kelompok intervensi dan 3 di kelompok kontrol) dengan teknik pengambilan sampel secara non-random menggunakan teknik purposive sampling.

Pengumpulan data pada penelitian ini dengan mengumpulkan data primer yang sesuai dengan variabel independen terapi akupresur yaitu pada kelompok Intervensi diberikan terapi akupresur di titik Yintang (EX-HN3) dan Shenmen (HT-7), selama 40-60 kali pemijatan yang berlawanan arah jarum jam, durasi 3 kali setiap minggu selama 4 minggu, pada kelompok kontrol tetap diberikan terapi pada placebo akupresur yaitu memberikan akupresur pada titik palsu dan variabel dependen tingkat kecemasan melalui pembagian kuesioner terkait karakteristik responden danlembar kuesioner kecemasan HARS (Hamilton Anxiety Rating Scale) yang terdiri dari 14 pertanyaan dengan rentang skor 0-4 dengan kriteria tingkat kecemasan skor $<14=$ Tidak ada kecemasan, skor 14-20=Kecemasan ringan, skor 2127=Kecemasan sedang, skor 28-41=Kecemasan berat, skor 42-56=Kecemasan berat sekali.

Penelitian ini telah dinyatakan layak etik oleh Komisi Etik Fakultas Kedokteran Universitas Hasanuddin nomor registrasi UH18100720. Analisis data menggunakan program software SPSS 22.0. Analisis data dalam penelitian ini menggunakan analisis univariate dan independent $t$ test.

\section{HASIL PENELITIAN}

Berdasarkan penelitian yang telah dilakukan, maka diperoleh hasil penelitian sebagai berikut:

Tabel 1 menunjukkan bahwa dari 40 orang total responden yang berpartisipasi pada penelitian ini, dibagi menjadi dua kelompok yaitu 21 orang kelompok intervensi dan 19 orang kelompok kontrol. Kedua kelompok ini juga menunjukkan bahwa karakteristik responden tidak berbeda $(p>0,05)$. Berdasarkan karakteristik usia, ratarata usia responden yang pada kelompok intervensi 28,0 tahun $(\mathrm{SD}=4,93)$ dan pada kelompok kontrol yaitu 28,5 tahun $(S D=4,46)$. Karakteristik pendidikan dengan jumlah responden tertinggi pada kelompok ibu hamil intervensi adalah mayoritas 
berpendidikan tinggi dengan jumlah 9 orang (42,9\%) Sedangkan pada kelompok ibu hamil kontrol adalah yang berpendidikan SMA dengan jumlah responden 11 orang (57,9\%). Karakteristik pekerjaan dengan jumlah responden tertinggi pada kelompok ibu hamil intervensi yang tidak bekerja terdapat 14 orang $(66,7 \%)$ dan pada kelompok kontrol sebanyak 17 orang $(89,5 \%)$ yang tidak bekerja. Karakteristik paritas dengan jumlah responden tertinggi pada kelompok ibu hamil intervensi dan kelompok ibu hamil kontrol terdapat pada ibu yang multigravida, pada kelompok ibu hamil intervensi sebanyak 14 orang $(66,7 \%)$ dan kelompok ibu hamil kontrol sebanyak 14 orang (73,7\%). Karakteristik berdasarkan usia kehamilan pada kelompok ibu hamil intervensi yang usia kehamilan 25-30 minggu sebanyak 11 orang $(52,4 \%)$ sedangkan pada kelompok ibu hamil kontrol yang usia kehamilan 25-30 minggu sebanyak 11 orang $(57,9 \%)$

Tabel 1. Karakteristik Responden Kelompok Intervensi dan Kelompok Kontrol

\begin{tabular}{|c|c|c|c|c|c|c|c|}
\hline \multirow{3}{*}{$\begin{array}{l}\text { Karakteristik } \\
\text { Usia }\end{array}$} & \multicolumn{4}{|c|}{ Kelompok Ibu Hamil } & \multirow{2}{*}{\multicolumn{2}{|c|}{ Total }} & \multirow[b]{2}{*}{$p$-value } \\
\hline & \multicolumn{2}{|c|}{$\begin{array}{l}\text { Intervensi } \\
\text { Mean } \pm \text { SD }\end{array}$} & \multicolumn{2}{|c|}{$\begin{array}{c}\text { Kontrol } \\
\text { Mean } \pm \text { SD }\end{array}$} & & & \\
\hline & 28,0 & 4,93 & 28,57 & 4,46 & & & $0,701 *$ \\
\hline & $\mathbf{n}$ & $\%$ & $\mathbf{n}$ & $\%$ & $\mathrm{n}$ & $\%$ & \\
\hline \multicolumn{8}{|l|}{ Pendidikan } \\
\hline SD & 1 & 4.8 & 1 & 5.3 & 2 & 5,0 & \\
\hline SMP & 3 & 14.3 & 2 & 10.5 & 5 & 12,5 & 0,632 \\
\hline SMA & 8 & 38.1 & 11 & 57.9 & 19 & 47,5 & \\
\hline PT & 9 & 42.9 & 5 & 26.3 & 14 & 35,0 & \\
\hline \multicolumn{8}{|l|}{ Pekerjaan } \\
\hline Bekerja & 7 & 33.3 & 2 & 10.5 & 9 & 22,5 & 0,085 \\
\hline Tidak Bekerja & 14 & 66.7 & 17 & 89.5 & 31 & 77,5 & \\
\hline \multicolumn{8}{|l|}{ Paritas } \\
\hline Primigravida & 7 & 33.3 & 5 & 26.3 & 12 & 30,0 & 0,629 \\
\hline Multigravida & 14 & 66.7 & 14 & 73.7 & 28 & 70,0 & \\
\hline \multicolumn{8}{|l|}{ Usia Kehamilan } \\
\hline 25-30 minggu & 11 & 52.4 & 11 & 57.9 & 22 & 55,0 & 0726 \\
\hline 30-36 minggu & 10 & 47.6 & 8 & 42.1 & 19 & 45,0 & $0, \pi<0$ \\
\hline
\end{tabular}

$S D=$ Standar Deviasi; Uji Homogenitas $>0,05 ; n=40$ orang (Kelompok Intervensi $n=21$ dan Kelompok Kontrol $n$ 19)

Tabel 2. Tingkat kecemasan Ibu Hamil Sebelum Intervensi dan Setelah Intervensi

\begin{tabular}{llrrrr}
\hline \multirow{2}{*}{ Waktu } & \multirow{2}{*}{ Kategori } & \multicolumn{4}{c}{ Kelompok lbu Hamil } \\
\cline { 3 - 6 } & & \multicolumn{3}{c}{ Intervensi } & \multicolumn{2}{c}{ Kontrol } \\
\cline { 3 - 6 } & & $\mathrm{n}$ & $\%$ & $\mathrm{n}$ & $\%$ \\
\hline Sebelum & Kecemasan Sedang & 14 & 66,7 & 17 & 89,5 \\
Intervensi & Kecemasan Berat & 7 & 33,3 & 2 & 10,5 \\
\hline Setelah & Kecemasan Ringan & 6 & 28,6 & 1 & 5,3 \\
Intervensi & Kecemasan Sedang & 14 & 66,7 & 15 & 78,9 \\
& Kecemasan Berat & 1 & 4,8 & 3 & 15,8 \\
\hline
\end{tabular}

Tabel 2 menunjukan karakteristik tingkat kecemasan ibu hamil sebelum intervensi menunjukkan jumlah responden pada ibu hamil kelompok intervensi yang mengalami kecemasan sedang sebanyak 14 orang $(66,7 \%)$ dan yang mengalami kecemasan berat sebanyak 7 orang (33,3\%). Sedangkan pada ibu hamil kelompok 
kontrol jumlah responden yang mengalami kecemasan sedang sebanyak 17 orang $(89,5 \%)$ dan yang mengalami kecemasan berat ada 2 orang $(10,5 \%)$.

Karakteristik tingkat kecemasan ibu hamil setelah intervensi menunjukkan jumlah responden pada ibu hamil kelompok intervensi yang mengalami kecemasan ringan sebanyak 6 orang $(28,6 \%)$, kecemasan sedang 14 orang $(66,7 \%)$, dan kecemasan berat 1 orang $(4,8 \%)$. Sedangkan pada ibu hamil kelompok kontrol menunjukkan jumlah responden yang mengalami kecemasan ringan ada 1 orang (5,3\%), kecemasan sedang sebanyak 15 orang $(78,9 \%)$ dan yang mengalami kecemasan berat ada 3 orang $(15,8 \%)$.

Tabel 3. Rerata kecemasan ibu hamil sebelum dan setelah intervensi pada kelompok intervensi dan kelompok kontrol

\begin{tabular}{|c|c|c|c|}
\hline \multirow{2}{*}{ Kecemasan Ibu Hamil } & \multicolumn{2}{|c|}{ Kelompok Ibu Hamil } & \multirow{2}{*}{$p$-Value } \\
\hline & Intervensi & Kontrol & \\
\hline $\begin{array}{c}\text { Sebelum Intervensi } \\
\overline{\boldsymbol{x}} \pm S D\end{array}$ & $26.6 \pm 2.08$ & $26.1 \pm 1.7$ & 0.252 \\
\hline $\begin{array}{r}\text { Setelah intervensi } \\
\overline{\boldsymbol{x}} \pm S D\end{array}$ & $22.3 \pm 2.7$ & $25.1 \pm 2.5$ & 0.003 \\
\hline
\end{tabular}

$\mathrm{SD}$; Standar Deviasi; Kelompok intervensi $\mathrm{n}=21$; Kelompok kontrol $\mathrm{n}=19$; MannWhitney Test, pengukuran kecemasan dengan Hamilton Anxiety Rating Scale (HARS)

Tabel 3. menunjukkan bahwa tidak terdapat perbedaan kecemasan ibu hamil sebelum diberikan terapi akupresur pada kelompok intervensi dengan kelompok kontrol (Mean=26,61 Vs 26,1, $p=0,252$ ) dan terdapat perubahan yang signifikan terhadap tingkat kecemasan ibu hamil pada kelompok intervensi dan kelompok kontrol setelah diberikan terapi akupresur (Mean=22,3 Vs 25,1, $p=0,003$ ).

Tabel 4. Pengaruh terapi akupresur terhadap tingkat kecemasan ibu hamil sebelum dan setelah intervensi

\begin{tabular}{lcc}
\hline \multirow{2}{*}{ Waktu } & Kecemasan Ibu Hamil & \multirow{2}{*}{$p$-Value } \\
\cline { 2 - 2 } \pm Sebelum Intervensi & $26,6 \pm 1,9$ & \multirow{2}{*}{$<0,001$} \\
\hline Setelah Intervensi & $22.3 \pm 2.7$ & $<0$ \\
\hline
\end{tabular}

SD; Standar Deviasi; $\mathrm{n}=40 ;$ Mann-Whitney Test, Descriptive Statistics, pengukuran kecemasan dengan Hamilton Anxiety Rating Scale (HARS)

Tabel 4. menunjukkan bahwa akupresur berpengaruh terhadap penurunan tingkat kecemasan pada ibu hamil sebelum dan setelah intervensi (Mean 26,6 Vs 22.3, $p=<0,001)$.

Table 5. Pengaruh terapi akupresur terhadap tingkat kecemasan ibu hamil sebelum intervensi dan setelah intervensi pada setiap kelompok

\begin{tabular}{|c|c|c|c|}
\hline & Sebelum Intervensi & Setelah Intervensi & \\
\hline Kelompok & $\bar{x} \pm S D$ & $\bar{x} \pm S D$ & $\rho$-value \\
\hline Intervensi & $26.6 \pm 1.9$ & $22.3 \pm 2.7$ & $<0,001$ \\
\hline Kontrol & $26.1 \pm 1.7$ & $25.1 \pm 2.5$ & 0,072 \\
\hline
\end{tabular}

SD; Standar Deviasi; Kelompok intervensi $\mathrm{n}=21$; Kelompok kontrol $\mathrm{n}=19$; Wilcoxon Signed Ranks Test, pengukuran kecemasan dengan Hamilton Anxiety Rating Scale (HARS); 
Table 5. Menunjukkan bahwa rerata tingkat kecemasan ibu hamil pada kelompok intervensi sebelum intervensi adalah $(26,6)$ dan setelah intervensi adalah $(22,3)$ dengan nilai $p<0,001$ yang berarti terapi akupresur berpengaruh terhadap penurunan tingkat kecemasan pada ibu hamil.

Sedangkan pada kelompok kontrol rerata tingkat kecemasan ibu hamil sebelum intervensi placebo adalah $(26,1)$ dan setelah intervensi placebo rerata tingkat kecemasan adalah $(25,1)$ dengan nilai $p=0,072$ yang berarti terapi placebo tidak menurunkan tingkat kecemasan ibu hamil. Berdasarkan rerata penurunan tingkat kecemasan kehamilan kelompok intervensi lebih bermakna dibandingkan kelompok kontrol (Selisih $=-4,28$ Vs -1,05).

\section{PEMBAHASAN}

Sesuai dengan tujuan dan hipotesis pada penelitian ini yaitu untuk mengetahui pengaruh terapi akupresur terhadap kecemasan maka dilakukan penelitian eksperimen semu (Quasi Eksperiment), dengan pendekatan pre and post-test pada kelompok intervensi dan kelompok kontrol. Hasil penelitian ini didapatkan bahwa sebagian besar responden sebelum intervensi mengalami tingkat kecemasan sedang dan berat baik pada ibu hamil kelompok intervensi dan kontrol. Setelah diberikan terapi akupresur frekuensi tingkat kecemasan ibu hamil pada kelompok intervensi mengalami perubahan yaitu sebagian besar mengalami kecemasan sedang, selebihnya mengalami kecemasan ringan dan dan ada beberapa mengalami kecemasan berat. Sedangkan pada keompok kontrol sebagian besar mengalami kecemasan sedang, selebihnya mengalami kecemasan berat dan paling sedikit mengalami kecemasan ringan.

Tingkat kecemasan ibu hamil diketahui dengan ada atau tidaknya gejala psikologis dan somatik namun tidak memperhatikan faktor lain yang dapat berpengaruh terhadap peningkatan atau penurunan gejala kecemasan, sehingga penurunan kecemasan dapat terjadi pada semua kelompok baik pada kelompok intervensi maupun kelompok kontrol.

Gejala kecemasan selama kehamilan lebih tinggi dibandingkan dengan pada saat persalinan dan masa nifas. Gejala ini berubah-ubah pada saat antenatal dan transisi gejala berbeda setiap individu. Hal tersebut terjadi karena respon cemas seseorang tergantung pada kematangan pribadi, pemahaman dalam menghadapi tantangan, harga diri, dan juga mekanisme pertahanan diri yang digunakan untuk mengatasi kecemasannya antara lain dengan menekan konflik, implus-implus yang tidak dapat diterima secara sadar, tidak mau memikirkan hal-hal yang kurang menyenangkan dirinya (supresi) (Stuart, 2007).

Ibu hamil yang mengalami kecemasan kehamilan berisiko depresi pada saat postpartum, peningkatan risiko kelahiran premature dan BBLR. Mengingat risiko yang begitu besar sehingga perlu dilakukan upaya-upaya untuk mengurangi kecemasan kehamilan baik secara farmakologis maupun secara non farmakologis.

Penelitian ini menunjukkan bahwa tidak terdapat perbedaan kecemasan ibu hamil sebelum diberikan terapi akupresur pada kelompok intervensi dengan kelompok kontrol dan terjadi penurunan yang signifikan terhadap tingkat kecemasan ibu hamil setelah diberikan terapi akupresur. Penggunaan akupresur mengurangi kecemasan pada wanita post operasi Sectio Caesar (Chen et al., 2005; Kuo et al., 2016). Penelitian yang lain juga menunjukkan hasil bahwa terdapat perbedaan yang signifikan rata - rata kecemasan pada pasien pra operasi abdomen sebelum intervensi sedangkan pada kelompok placebo tidak signifikan sebelum intervensi akupresur dan setelah intervensi akupresur (Abadi et al., 2018; Valiee et al., 2012). 
Beberapa Penelitian tersebut menunjukkan bahwa peptide dan neurotransmitter tertentu dapat dibebaskan selama proses akupresur yang berdampak pada penurunan fungsi system saraf simpatis sehingga mengurangi kecemasan dan memberikan rasa nyaman pada seseorang.

Perubahan tingkat kecemasan pada penelitian ini bervariasi antara kelompok ibu hamil intrervensi dan kelompok ibu hamil kontrol. Umumnya penurunan tingkat kecemasan terjadi pada minggu ketiga dan keempat intervensi yang dibuktikan dengan penurunan nilai HARS. Penelitian ini sejalan dengan penelitian yang dilakukan (Hmwe et al., 2015) bahwa akupresur diberikan pada 15 orang untuk menurunkan gejala pernapasan dapat dilakukan dengan empat kali akupresur dan untuk penurunan kecemasan yang signifikan dilakukan akupresur dengan frekuensi tiga kali seminggu selama empat minggu.

Akupresur merupakan jenis pengobatan non farmakologis dengan menggunakan penekanan titik - titik tertentu pada tubuh untuk merangsang proses penyembuhan serta diyakini untuk meningkatkan kesehatan psikologi (Valiee et al., 2012). Stimulasi acupoint diyakini menguatkan dan melemahkan energi (Qi) untuk meningkatkan vitalitas organ tubuh sehingga dapat meningkatkan kesehatan tubuh dan energi akupresur pada titik akupunktur akan mengalir melalui aliran meridian menuju target organ. Stimulasi maupun sedasi target organ akan memberikan efek perubahan persepsi/rasa yang dapat berupa rasa nyaman dan tenang (Bussel, Spitz and Demyttenaere, 2009; Adikara, 2015).

Terapi akupresur merupakan pilihan terapi non farmakologis yang efektif menurunkan kecemasan pada ibu hamil sehingga dapat dijadikan sebagai upaya rehabilitatif yang mana dilakukan sebagai pertolongan pertama bagi ibu yang mengalami gejala-gejala kecemasan yang mengancam kehamilan beserta janinnya dan sebagai upaya promotif dilakukan untuk mencegah terjadinya masalah kecemasan karena stressor yang tidak dapat dihindarkan.

\section{SIMPULAN DAN SARAN}

Berdasarkan hasil penelitian yang dilakukan membuktikan bahwa terapi akupresur pada titik EX-HN3 dan HT-7 dengan frekuensi 3 kali seminggu selama 4 minggu dapat menurunkan tingkat kecemasan ibu hamil, sehingga akupresur dapat dijadikan sebagai salah satu pilihan intervensi non farmakologis yang aman dan murah bagi ibu hamil mengatasi masalah kecemasan kehamilan. penelitian selanjutnya diharapkan melakukan pemeriksaan hormon secara time series.

\section{UCAPAN TERIMA KASIH}

Peneliti menyampaikan terima kasih kepada pihak yang telah berkontribusi dan memberikan dukungan untuk terlaksananya kegiatan penelitian ini, antara lain Direktur Akademi Kebidanan Batari Toja Watampone, Dinas Kesehatan Kota Makassar, Kepala Puskesmas Antang, Kepala Puskesmas Tamalanrea Makassar.

\section{DAFTAR PUSTAKA}

Abadi, F., Abadi, F., Fereidouni, Z., Amirkhani, M., Karimi, S., \& Najafi Kelyani, M. (2018). Effect of Acupressure on Preoperative Cesarean Section Anxiety. Journal of Acupuncture and Meridian Studies, 11(6), 361-366. https://www.sciencedirect.com/science/article/pii/S2005290118300165

Adikara. (2015). Pelatihan Terapi Komplementer Alternatif \& Akupresur untuk Dokter, Perawat, Bidan dan Umum. Asosiasi Chiro-practor dan Akupreser Seluruh Indonesia (ACASI) Cabang Bondowoso.

Arami, S., Kazemi, M., Esmaeili, \& Nadimi, A. (2015). Comparing The Effect Of Acupressure 
Points Shenmen (HE7) With A Third Eye On Anxiety In Patients Undergoing Coronary Angiography. Medical-Surgical Nursing Journal., 4(2), 1-6. https://www.sid.ir/en/Journal/ViewPaper.aspx?ID=456653

Brummelte, S., \& Galea, L. A. M. (2010). Depression during pregnancy and postpartum: Contribution of stress and ovarian hormones. Progress in Neuro-Psychopharmacology and Biological Psychiatry, 34(5), 766-776. https://doi.org/10.1016/j.pnpbp.2009.09.006

Bussel, J. C. H. Van, Spitz, B., \& Demyttenaere, K. (2009). Anxiety in pregnant and postpartum women. An exploratory study of the role of maternal orientations. Journal of Affective Disorders, 114(1-3), 232-242. https://doi.org/10.1016/j.jad.2008.07.018

Chen, H.-M., Chang, F.-Y., \& Hsu, C.-T. (2005). Effect of Acupressure on Nausea, Vomiting, Anxiety and Pain among Post-cesarean Section Women in Taiwan. The Kaohsiung Journal of Medical Sciences, 21(8), 341-350. https://doi.org/10.1016/S1607$551 \times(09) 70132-9$

Deklava, L., Lubina, K., Circenis, K., Sudraba, V., \& Millere, I. (2015). Causes of Anxiety during Pregnancy. Procedia - Social and Behavioral Sciences, 205(May), 623-626. https://doi.org/10.1016/j.sbspro.2015.09.097

Hmwe, N. T. T., Subramanian, P., Tan, L. P., \& Chong, W. K. (2015). The effects of acupressure on depression, anxiety and stress in patients with hemodialysis: A randomized controlled trial. International Journal of Nursing Studies, 52(2), 509-518. https://pubmed.ncbi.nlm.nih.gov/25468282/

Kao, C. L., Chen, C. H., Lin, W. Y., Chiao, Y. C., \& Hsieh, C. L. (2012). Effect of auricular acupressure on peri- and early postmenopausal women with anxiety: A double-blinded, randomized, and controlled pilot study. Evidence-Based Complementary and Alternative Medicine, 2012. https://doi.org/10.1155/2012/567639

Kuo, S. Y., Tsai, S. H., Chen, S. L., \& Tzeng, Y. L. (2016). Auricular acupressure relieves anxiety and fatigue, and reduces cortisol levels in post-caesarean section women: A single-blind, randomised controlled study. International Journal of Nursing Studies, 53, 17-26. https://doi.org/10.1016/j.jinurstu.2015.10.006

Lee, A. M., Lam, S. ., Sze Mun Lau, S. M., Chong, C. S., Chui, H. W., \& Fong, D. Y. (2007). Prevalence, course, and risk factors for antenatal anxiety and depression. Obstet. Gynecol, 101(5), 1102-1112. https://pubmed.ncbi.nlm.nih.gov/17978126/

Lubis, N. L. (2009). Depresi Tinjauan Psikologi. PT Fajar Interpratama Mandiri.

Madhavanprabhakaran, G. K., D'Souza, M. S., \& Nairy, K. S. (2015). Prevalence of pregnancy anxiety and associated factors. International Journal of Africa Nursing Sciences, 3, 1-7. https://doi.org/10.1016/j.jjans.2015.06.002

Mizuno, T., Tamakoshi, K., \& Tanabe, K. (2017). Anxiety during pregnancy and autonomic nervous system activity: A longitudinal observational and cross-sectional study. Journal of Psychosomatic Research, 99, 105-111. https://doi.org/10.1016/j.jpsychores.2017.06.006

Qiao, Y., Wang, J., Li, J., \& Wang, J. (2012). Effects of depressive and anxiety symptoms during pregnancy on pregnant, obstetric and neonatal outcomes: A follow-up study. Journal of Obstetrics and Gynaecology, 32(3), 237-240. https://doi.org/10.3109/01443615.2011.647736

Siregar, N. Y., Kias, C. F., Nurfatimah, N., Noya, F., Longgupa, L. W., Entoh, C., \& Ramadhan, K. (2021). Tingkat Kecemasan Ibu Hamil Trimester III dalam Menghadapi Persalinan. Jurnal Bidan Cerdas, 3(1), 18-24. https://doi.org/10.33860/jbc.v3i1.131

Stuart, G. (2007). Buku Saku Keperawatan Jiwa (5th ed.). ECG.

Talge, N. M., Neal, C., \& Glover, V. (2007). Antenatal maternal stress and long-term effects on child neurodevelopment: how and why? Journal of Child Psychology and Psychiatry, 48(3-4), 245-261. https://doi.org/10.1111/j.1469-7610.2006.01714.x

Teixeira, C., Figueiredo, B., Conde, A., Pacheco, A., \& Costa, R. (2009). Anxiety and depression during pregnancy in women and men. Journal of Affective Disorders, 119(13), 142-148. https://doi.org/10.1016/j.jad.2009.03.005

The British Psychological Society. (2018). Antenatal and postnatal mental health clinical management and service guidance. December 2014. 
Valiee, S., Bassampour, S. S., \& Nasrabadi, A. N. (2012). Effect of Acupressure on Preoperative Anxiety: A Clinical Trial. Journal of PeriAnesthesia Nursing, 27(4), 259 266. https://doi.org/10.1016/j.jopan.2012.05.003

Videbeck, S. (2012). Buku Ajar Keperawatan Jiwa. ECG.

Vlenterie, R., Roeleveld, N., \& van Gelder, M. M. H. J. (2016). Single awakening salivary measurements provide reliable estimates of morning cortisol levels in pregnant women. Psychoneuroendocrinology, 74 , 295-301. https://doi.org/10.1016/j.psyneuen.2016.09.009

Yuksel, F., Akin, S., \& Durna, Z. (2014). Prenatal distress in Turkish pregnant women and factors associated with maternal prenatal distress. Journal of Clinical Nursing, 23(1-2), 54-64. https://doi.org/10.1111/j.1365-2702.2012.04283.x 